\title{
New Species of Austrothaumalea Tonnoir from Australia (Diptera: Thaumaleidae)
}

\author{
BRADLEY J. SINCLAIR \\ Entomology-Ontario Plant Laboratories, Canadian Food Inspection Agency, \\ K.W. Neatby Bldg., C.E.F., 960 Carling Ave., Ottawa, ON Canada K1A 0C6, Canada \\ sinclairb@inspection.gc.ca
}

\begin{abstract}
Seven new eastern Australian species of Austrothaumalea Tonnoir are described (A. bicornis, A. bifida, A. concava, A. queenslandensis, A. ramosa, A. theischingeri, A. uloola). Notes and new collection records of previously described Australian species of Austrothaumalea and Niphta Theischinger are listed and an updated key to all described Australian species of Austrothaumalea provided. Assignment of species of Austrothaumalea to species groups is also presented. The known distribution of eastern Australian Thaumaleidae is extended to northern Queensland.
\end{abstract}

Sinclair, BRAdLey J., 2008. New species of Austrothaumalea Tonnoir from Australia (Diptera: Thaumaleidae). Records of the Australian Museum 60(1): 1-12.

In the Australasian region, three genera of Thaumaleidae (Diptera) are known: Austrothaumalea Tonnoir, Niphta Theischinger and Oterere McLellan (Theischinger, 1986; McLellan, 1988). Niphta is a small genus with three Australian and one South American species (Theischinger, 1986). It is possibly most closely related to Afrothaumalea Stuckenberg (Sinclair \& Stuckenberg, 1995). Oterere is known from one New Zealand species and one South American species and appears most closely related to Austrothaumalea. There are ten species of Austrothaumalea from New Zealand, three from South America, one species from New Caledonia (Sinclair, in press), and prior to this study, 19 species from Australia.

In Australia, one species of Austrothaumalea is confined to the southwest, four species confined to Tasmania and the remaining species prior to this study were found from Victoria to southern Queensland (Theischinger, 1986). To my knowledge there are currently no records of thaumaleids from northern Queensland. In this study, seven new species of Austrothaumalea are described, the key to Australian species is updated to include these new species and new collection records are listed for previously described Australian species.

\section{Materials and methods}

Terms used for adult structures primarily follow those of J.F. McAlpine (1981), except wing venation where the interpretations of Colless \& D.K. McAlpine (1991, fig. 39.17F) and Saigusa (2006) are accepted. Homology of the male terminalia follows that of Sinclair (1992). All specimens in this study were collected by the author.

This study is based on more than 350 adult specimens deposited in the following institutions: Australian Museum, Sydney (AMS); Australian National Insect Collection, Canberra (ANIC); Canadian National Collection of Insects, Ottawa, Canada (CNC); Zoologisches Forschungsmuseum Alexander Koenig, Bonn, Germany (ZFMK). Label data for primary types are cited in full, with labels listed from the top downward, and data from each label enclosed in quotation marks. Labels are cited in full, in original spelling, punctuation and date, and lines are delimited by a slash mark (/). Additional information is included in [square] brackets. The repository of each type is given in parentheses. Secondary type data are abridged and listed alphabetically.

The above abbreviations are used throughout the text to 
indicate deposition of specimens. The following abbreviations are used in the material examined sections: $C k$, creek; $L k$, lake; $N P$, National Park; $n r$, near; $P k$, park; $R$, river; $S F$, State Forest; $S P$, State Park; temp. rainfor., temperate rainforest.

In Australia, thaumaleids were collected anywhere permanent water was flowing, and this included wet rainforests to dry sclerophyll forests and from lowlands to uplands. Adults were collected by sweeping cascading streams, edges of waterfalls, seepages and associated riparian vegetation. Larvae were observed in seepages and splash zones of emergent boulders in streams.

For best results, adult thaumaleids should be collected into $75 \%$ ethanol and later critical-point-dried. Dissection is much easier and details of the male terminalia in mounted specimens are often more readily observed when the material is prepared in this way.

Key to males of Australian species of Austrothaumalea (modified from Theischinger, 1986)

$1 \quad \mathrm{R}_{4+5}$ with macrosetae

A. tasmanica Theischinger

$-\mathrm{R}_{4+5}$ lacking macrosetae

2 Gonostylus branched or forked (Fig. 3)

Gonostylus simple, unbranched, lacking additional lobes (Fig. 2)

3 Apex of paramere forked; inner lobe of gonostylus short, not longer than wide; apex of epandrium prolonged (Fig. 3)

A. bifida n.sp.

Apex of paramere simple; inner lobe of gonostylus longer than wide; apex of epandrium truncate (Theischinger, 1986, fig. 18)

4 Length of outer branch of gonostylus more than twice width A. cervulus Theischinger

Length of outer branch of gonostylus less than twice width A. uptoni Theischinger

5 Western Australian species A. australis Theischinger

Eastern Australian species 6

$6 \quad$ Epandrium (tergite 9) with apical or lateral processes .......................................................... 7

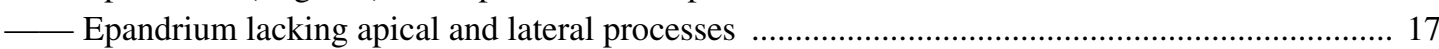

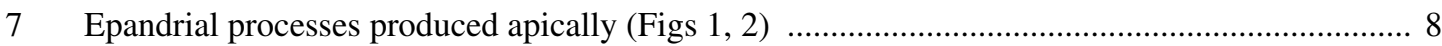

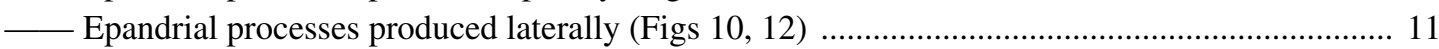

8 Epandrial processes long and very slender (Fig. 1), more than three times as long as basal width

Epandrial processes very short and subtriangular, slightly longer than basal width A. bickeli Theischinger

9 Gonostylus bent nearly at right angles at mid-length, apex expanded slightly (Figs 1-2) A. bicornis n.sp.

Gonostylus curved evenly throughout, apex tapered 10

10 Gonocoxal plate prolonged apically, arrowhead-shaped; epandrium with broad, rounded lateral lobe posterior to gonocoxite....

A. minnamurrae Theischinger

Gonocoxal plate truncate apically, with pair of short, slender apicolateral processes; lateral margin of epandrium slightly expanded, lacking distinct prolongation (Woombye, Qld) Austrothaumalea sp.

[see Remarks section for A. minnamurrae; Theischinger, 1986: 304]

11 Gonostylus curved evenly throughout (Figs 9, 11)

Gonostylus bowed strongly near mid-length, basal and apical portions almost straight (Theischinger, 1986, fig. 38)

12 Paramere long, slender and sword-like, approximately $2 \times$ length of gonocoxal plate; gonocoxal plate bearing apicolateral crown of pointed projections

Paramere short, laterally flattened with rounded apex, at most $1.5 \times$ length of gonocoxal plate; gonocoxal plate lacking crown of pointed projections or only forked processes apicolaterally (Figs 9, 11) 
13 Epandrium narrowly produced between lateral processes, longer than wide; lateral processes arching inwards to oppose each other

A. spinosa Theischinger

Epandrium broadly extended beyond lateral processes; lateral processes not arching inwards to oppose each other

14 Lateral processes of epandrium long and horn-like; gonocoxal plate with apicolateral spine-like processes; anterior margin of hypandrium partially U-shaped; apex of gonostylus smooth A. capricornis Theischinger

_ Lateral processes of epandrium short and subtriangular; gonocoxal plate umbrella-shaped, lacking spines; anterior margin of hypandrium deeply U-shaped; apex of gonostylus slightly notched

A. victoriae Theischinger

15 Gonocoxal plate tapered apically with cup-like depression (Fig. 11) A. uloola $\mathrm{n} . \mathrm{sp}$.

_ Gonocoxal plate with pair of forked apicolateral processes (Fig. 9) A. theischingeri $\mathrm{n} . \mathrm{sp}$.

16 Lateral processes of epandrium long and horn-like, subequal to width of apical lobe A. similis Theischinger

_ Lateral processes of epandrium short and subtriangular; shorter than width of apical lobe A. denticulata Theischinger

17 Gonostylus strongly bent near mid-length or apical two-thirds (Fig. 8)

_ Gonostylus curved evenly throughout (Fig. 4)

18 Base of gonostylus roundly expanded; apical epandrial margin straight; gonocoxal plate with small apicolateral knobs A. macalpinei Theischinger Base of gonostylus not expanded; apical epandrial margin slightly notched; gonocoxal plate with long, antler-like processes (Fig. 8) A. ramosa n.sp.

19 Gonostylus tapered evenly throughout (Fig. 4) 20 Gonostylus nearly parallel-sided for about basal two-thirds; apical third abruptly reduced and slender (Theischinger, 1986, fig. 23)

20 Paramere with subapical pair of slender coiled processes A. simplex Theischinger Paramere simple, straight, lacking processes

21 Posterior margin of epandrium with narrow U-shaped median excision

Posterior margin of epandrium lacking narrow excision, straight

22 Posterior margin of epandrium broadly infolded (Fig. 5), apex somewhat narrowed and broadly pointed; apex of paramere setose; inner margin of gonocoxal lobes deeply concave (Fig. 4) A. concava n.sp.

- Posterior margin of epandrium not infolded, apex nearly straight; apex of paramere bare; inner margin of gonocoxal lobes nearly straight or only slightly concave (Fig. 6)

23 Apex of gonocoxal plate apparently deeply Y-shaped, although membranous sheet connecting arms may be visible (Fig. 6)

Apex of gonocoxal plate truncate, not apparently Y-shaped

24 Apex of paramere straight; gonocoxal plate with pair of apicolateral, knob-like processes; posterior margin of epandrium somewhat roughened or uneven with several small knobs (Fig. 6) A. queenslandensis n.sp. Apex of paramere slightly twisted and hooked ventrally; gonocoxal plate lacking apicolateral, knob-like processes; posterior margin of epandrium straight or with shallow depression, lacking knobs 
25 Gonocoxal plate umbrella-shaped; epandrium very short, only slightly longer than tergite 8 A. barrydayi Theischinger

Gonocoxal plate nearly square, truncate; epandrium longer than tergite 8 A. fusca Theischinger

26 Posterior margin of epandrium trapezoidal with rounded posterior corners; apical margin infolded; paramere long and slender, more than $2 \times$ length of gonocoxal plate; gonocoxal plate slightly prolonged apicolaterally A. tonnoiri Theischinger

Posterior margin of epandrium narrowed apically, with pair of very small triangular lateral processes; paramere not more than $2 \times$ length of gonocoxal plate; gonocoxal plate Y-shaped, with lateral arms arched around paramere bearing fingerlike processes

A. commoni Theischinger

\section{Taxonomy}

\section{Genus Austrothaumalea Tonnoir}

Austrothaumalea Tonnoir, 1927: 109

The genus Austrothaumalea is characterized by absence of a distinct ridge (supra-alar region) in front of the wing, microtrichia of first vein $\left(R+R_{1}+R_{1+2}\right)$ extending length of vein, crossvein closer to apex of $R_{1+2}$ than to origin of $R_{3}$, $\mathrm{R}_{3}$ often with arch strongly produced, basal appendage of $\mathrm{CuA}$ often present, gonocoxites slender, longer than wide and hypandrium broad.

\section{Austrothaumalea barrydayi Theischinger}

Austrothaumalea barrydayi Theischinger, 1986: 297

Material examined. New South Wales: 1 tô, Blue Mtns NP, Blackheath, Govetts Leap, 17.x.2002 (ZFMK); $3 \hat{\delta} \hat{\sigma}$, Blue Mtns NP, Blackheath, Grose Gorge, Govetts Ck, 1.xii.1993 (ANIC); 50 t 0 , 1 우, Blue Mtns NP, Blackheath, Popes Glen Ck, 1000 m, 31.x.1994 (AMS);

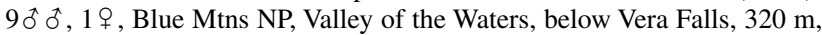

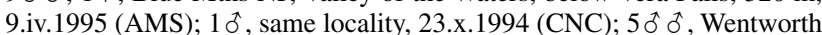
Falls, Jamison Ck \& seeps, 10.xi.1993, 23.x.1994 (CNC).

Distribution. This species is known from the southern half of eastern New South Wales.

Remarks. The gonocoxal plate bears a crown of minute denticles along the ventral margin, directed anteriorly and is not shown in Theischinger (1986, fig. 8).

\section{Austrothaumalea bickeli Theischinger}

Austrothaumalea bickeli Theischinger, 1988: 212.

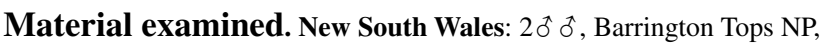
Williams R, 480 m, subtrop. rainfor., 19.xii.1993 (AMS, CNC).

Distribution. This species remains known only from Barrington Tops National Park.

\section{Austrothaumalea bicornis n.sp.}

$$
\text { Figs 1-2 }
$$

Type material. HoLOTYPE ơ "AUST: N.QLD: Mt. /Elliot N.P., $600 \mathrm{~m}$ /above Alligator Ck. /Falls, 9.iv.1994; seep /B.J. Sinclair"; "HOLOTYPE /Austrothaumalea /bicornis /Sinclair" (AMS). PARATYPES: Queensland: $1 \delta^{\lambda}$, same data as holotype (AMS).

Recognition. This species is distinguished by the strongly bent gonostyli and pair of long, slender apical epandrial processes.
Description. Wing length $1.5 \mathrm{~mm}$. Coloration: Head dull, dark brown. Mesonotum and pleura dark brown and dull; coxae, femora and tibiae pale brown, tarsi darker; halter knob pale on inner margin; abdomen dull greyish-brown, including pleural membrane; terminalia dark brown. Wing faintly infuscate; $R+R_{1}+R_{1+2}$ with macrotrichia along entire length, remaining veins bare; $R_{2}$ situated in middle of $R_{1+2}$; bend in $R_{3}$ strong; $R_{3}$ and $R_{4+5}$ somewhat divergent toward wing margin; $\mathrm{CuA}$ nearly straight, lacking appendage. Male abdominal sternites 2-7 rectangular, sparsely setose; sternite 8 membranous. Male terminalia (Figs 1-2): Epandrium broadly triangular from ventral aspect; posterior margin narrow, straight; pair of long, slender processes projecting from posterolateral margin. Hypandrium broad, less than width of base of gonostylus. Gonocoxite long, slightly tapered apically. Gonostylus bent at right angle near midlength; apex flattened, spatula-shaped from posterior view; lacking setulae beyond bend. Parameres fused to form laterally flattened process, with hooked tip; not extending beyond gonocoxites. Gonocoxal plate broad, extending to mid-length of gonocoxites; apical margin convex, with short posterolateral processes; not fused to hypandrium.

Distribution. This species is know only from its type locality (just south of Townsville, Queensland), collected from a seepage flowing over a large open rock bald next to the falls of Alligator Creek. Mount Elliot is a granite massif, arising more than $1000 \mathrm{~m}$. Its eastern slopes bear numerous small creeks and waterfalls. A small remnant rainforest is confined to areas above $600 \mathrm{~m}$.

Remarks. This species appears most closely related to $A$. minnamurrae and the undescribed species from Woombye referred to in Theischinger (1986).

Etymology. The specific name is from the Latin cornis (horned), in reference to the pair of long slender projections from the posterior margin of the epandrium.

\section{Austrothaumalea bifida n.sp.}

Fig. 3

Type material. HoLOTYPE 0 “AUST: N.QLD: Mt. /Elliot N.P., $600 \mathrm{~m}$ /above Alligator Ck. /Falls, 9.iv.1994; seep /B.J. Sinclair”; "HOLOTYPE /Austrothaumalea /bifida /Sinclair [dissected]" (AMS). PARATYPES: Queensland: $10,5 \% \uparrow$, same data as holotype (AMS).

Recognition. This species is distinguished by the bifid gonostylus and forked apex of the paramere. 

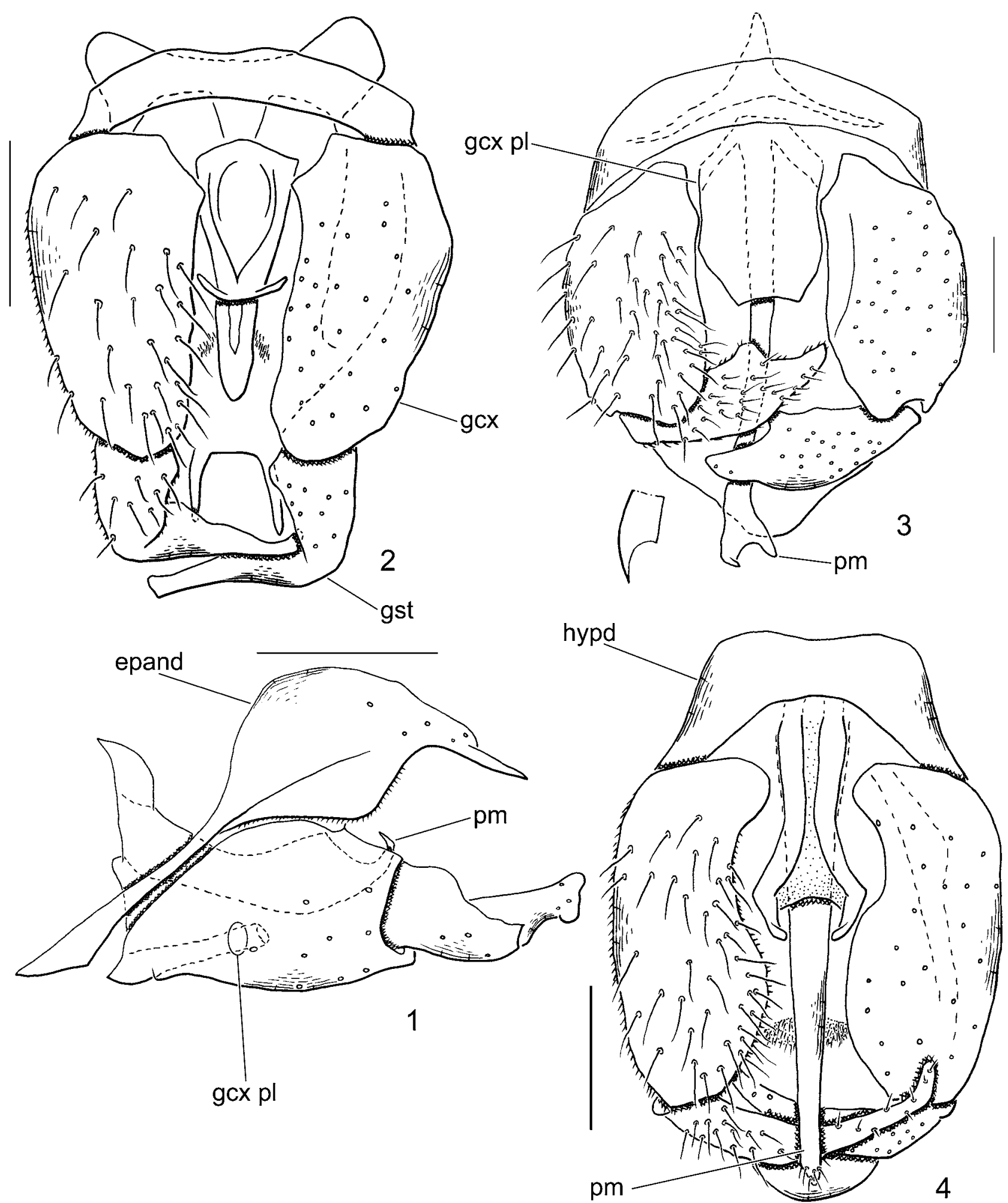

Figs 1-4. Male terminalia of Austrothaumalea: (1) A. bicornis, lateral view; (2) A. bicornis, ventral view; (3) A. bifida, ventral view (holotype), tip of paramere from paratype; (4) A. concava, ventral view. Scale bar $=0.1 \mathrm{~mm}$. Abbreviations: epand, epandrium; gcx, gonocoxite; gcx pl, gonocoxal plate; gst, gonostylus; hypd, hypandrium; pm, paramere.

Description. Wing length 1.7-2.0 mm. Coloration: Head dull, dark brown. Mesonotum and pleura dark brown and somewhat shiny; coxae, femora and tibiae pale brown, tarsi darker; halter knob pale on inner margin; abdomen dull greyish-brown, including pleural membrane; terminalia generally dark. Wing faintly infuscate; $\mathrm{R}+\mathrm{R}_{1}+\mathrm{R}_{1+2}$ with macrotrichia along entire length, remaining veins bare; $R_{2}$ situated towards apex of $\mathrm{R}_{1}$; bend in $\mathrm{R}_{3}$ gentle, not strongly defined; $\mathrm{R}_{3}$ and $\mathrm{R}_{4+5}$ divergent toward wing margin; $\mathrm{CuA}$ with short basal appendage. Male abdominal sternite 1, 
narrow, spectacle-shaped; sternite 2 reduced to slender, median sclerite, with pair of small, posterolateral sclerites; sternites 3-6 rectangular, sparsely setose; sternite 7 narrow, one-half length of sternite 6; sternite 8 reduced to Y-shaped sickle. Male terminalia (Fig. 3): Epandrium broadly triangular from ventral aspect; posterior margin narrow, evenly rounded; lacking pointed posterolateral processes. Hypandrium broad, less than width of base of gonostylus. Gonocoxite long, slightly expanded apically. Gonostylus mitten-shaped; thumb-like appendage short, truncate; apical process tapering and lacking setulae. Parameres fused to form long tube, arching dorsally, with abrupt subapical bend directly posteriorly; apex broadly forked (holotype) or sickle-shaped (paratype); extending beyond epandrium. Gonocoxal plate broad; apical margin concave, generally very pale; not fused to hypandrium.

Distribution. This species was collected from the same site as A. bicornis, south of Townsville, Queensland.

Etymology. The specific name is from the Latin bifidus (bifurcated), referring to the apex of the paramere.

Remarks. This species appears to be closely related to $A$. cervulus and $A$. uptoni on the basis of their bifid gonostylus and truncate gonocoxal plate. The apex of the paramere of A. bifidus differs between the holotype (forked) and paratype (sickle-shaped) (Fig. 3), a similar variation in the apex of the paramere was also noted in A. commoni (Theischinger, 1986, figs 25-26).

\section{Austrothaumalea capricornis Theischinger}

Austrothaumalea capricornis Theischinger, 1986: 298.

Material examined. New South Wales: $3 \hat{\delta} \delta, 1 q$, Blue Mtns NP, Mt. Wilson, Waterfall Ck, 22.xi.1993, 13.xii.1998 (AMS, CNC).

Distribution. This species is known from Mt. Wilson and the Point Lookout region of New England National Park.

Remarks. The above specimens from Mt. Wilson were collected either along a narrow cascading stream or at the waterfall near the edge of the forested region. This locality is a small remnant rainforest growing in rich basaltic soils, and near the stream is a large grove of tree ferns (Dicksonia antarctica Labill).

\section{Austrothaumalea cervulus Theischinger}

Austrothaumalea cervulus Theischinger, 1986: 298.

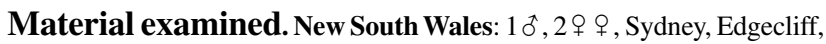
Trumper Pk, cliff seepage, 9.x.1994 (AMS).

Distribution. This species is known only from east of the Blue Mountains, in the Sydney, Royal National Park region.

Remarks. The paramere of $A$. cervulus bears a pair of subapical fang-like lateral processes, directed anteriorly, which are not shown in Theischinger (1986, fig. 18).

\section{Austrothaumalea commoni Theischinger}

Austrothaumalea commoni Theischinger, 1986: 300.

Material examined. New South Wales: $1 \hat{\jmath}$, Kosciusko NP, Thredbo, roadcut seeps, $1300 \mathrm{~m}, 28 . x i .1994$ (AMS).

Distribution. This species is known from southeastern New South Wales.

\section{Austrothaumalea concava n.sp.}

\section{Figs 4-5}

Type material. HoLOTYPE $\widehat{0}$ "AUST: QLD: Bunya /Mtns NP, Paradise /Falls, 8.x.2002 /B.J. Sinclair"; "HOLOTYPE /Austrothaumalea /concava /Sinclair" (AMS). PARATYPES: New South Wales: $1 \hat{\delta}$, Dorrigo NP, Wonga Walk, 700 m, Crystal Shower Falls, 2.iv.1995, B.J. Sinclair

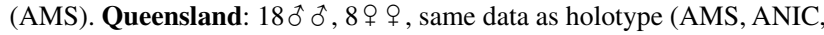
CNC, ZFMK).

Recognition. This species is distinguished by the concave inner margin of the gonocoxites, folded apical margin of the epandrium and short forked apex of the gonocoxal plate.

Description. Wing length $2.2 \mathrm{~mm}$. Coloration: Head dull, dark brown. Thorax yellowish-brown, somewhat shiny; legs pale yellow, becoming darker on apical tarsal segments; halter knob brown; abdomen dull greyish-brown, including pleural membrane; terminalia pale brown. Wing evenly infuscate; $\mathrm{R}+\mathrm{R}_{1}+\mathrm{R}_{1+2}$ with macrotrichia along entire length, remaining veins bare; $R_{2}$ situated towards apex of $R_{1}$; bend in $R_{3}$ gentle; $\mathrm{R}_{3}$ and $\mathrm{R}_{4+5}$ divergent toward wing margin; $\mathrm{CuA}$ lacking basal appendage. Male abdominal sternite 1 comprising narrow band with broad-shaped posterior notch; sternite 2 reduced to slender, median sclerite, with broad, W-shaped, posterior apex; sternites 3-5 rectangular, sparsely setose; sternite 6 semicircular, anterior margin irregular; sternite 7 reduced to narrow, rectangular sclerite; sternite 8 membranous. Male terminalia (Figs 4-5): Epandrium broadly triangular from ventral aspect; posterior margin round, folded internally for third of length; lacking pointed posterolateral processes. Hypandrium broad, with shallow median notch; nearly one-half width of base of gonocoxite. Gonocoxite long, inner margin concave opposite gonocoxal plate; strongly tapered on apical fourth. Gonostylus long, gradually arched, tapering to blunt tip; apical half lacking setulae. Parameres fused to form long straight tube; apex strongly bent, bearing long setulae; extending beyond gonocoxites. Gonocoxal plate broad, with darkly sclerotized lateral margins, making it appear somewhat Y-shaped, secondarily fused to ventral surface of hypandrium; posterolateral corners produced into single pointed, curved process, surrounding paramere.

Distribution. This species is likely widespread throughout northern New South Wales and southeastern Queensland. This region of Australia is poorly collected for thaumaleids, which can often only be collected by hand. They are not attracted to colour pan traps and are extremely rare in flight intercept traps.

Etymology. The specific name is from the Latin concavus (hollowed or arched inward), referring to the distinctly concave inner margin of the gonocoxal lobes.

Remarks. This species somewhat resembles A. tonnoiri on the basis of the narrow infolded apex of the epandrium. 


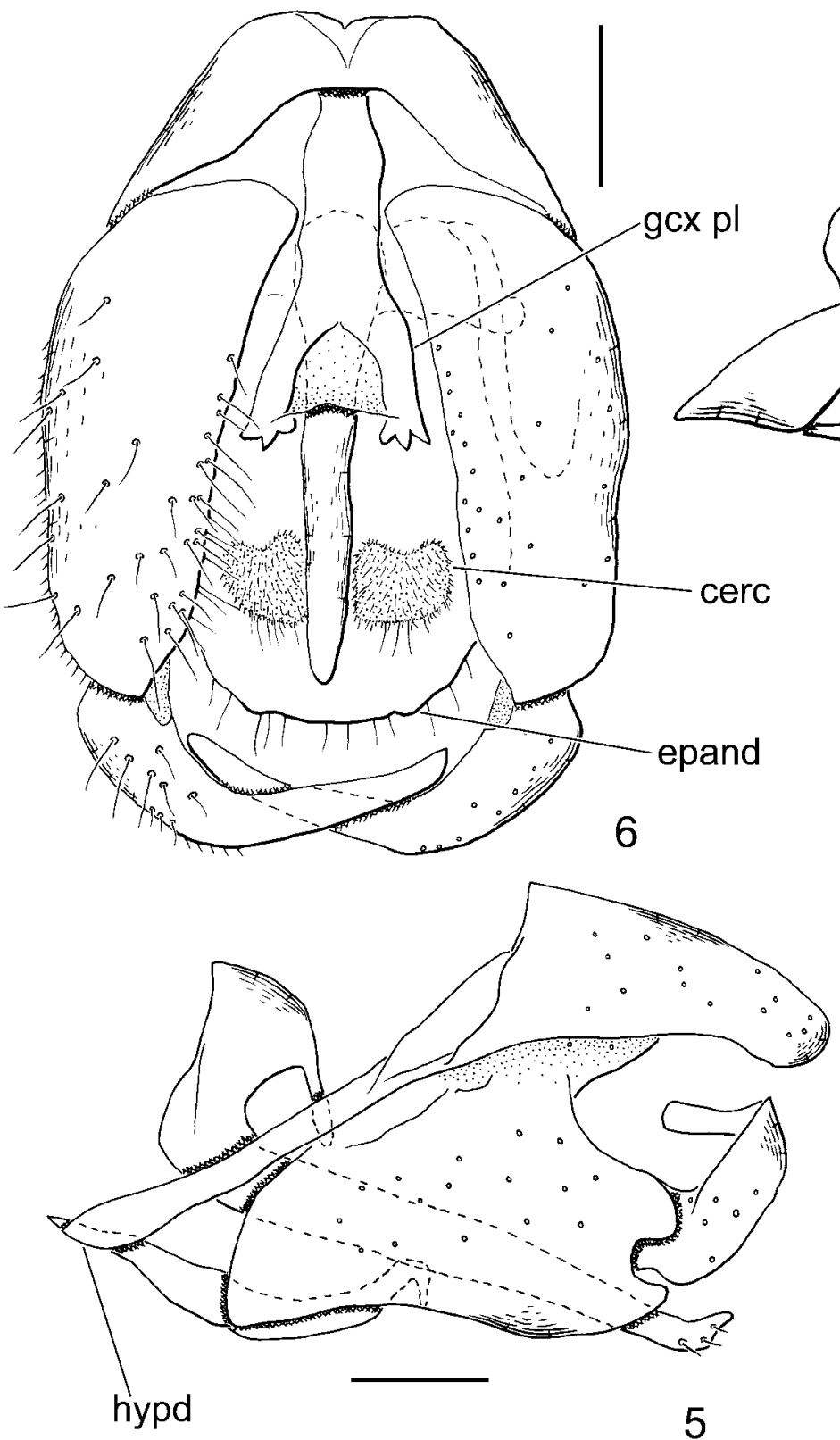

Figs 5-8. Male terminalia of Austrothaumalea: (5) A. concava, lateral view; (6) A. queenslandensis, ventral view; (7) A. ramosa, lateral view; (8) A. ramosa, ventral view. Scale bar $=0.1 \mathrm{~mm}$. Abbreviations: cerc, cercus; $g c x p l$, gonocoxal plate; gst, gonostylus; hypd, hypandrium; pm, paramere.

\section{Austrothaumalea denticulata Theischinger}

Austrothaumalea denticulata Theischinger, 1986: 301.

Material examined. New South Wales: $4 \hat{\jmath} \hat{\sigma}$, Blue Mtns NP,

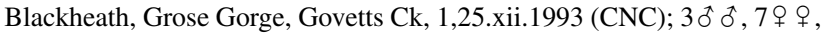
Blue Mtns NP, Grand Canyon, rainfor. stream, 25.xii.1993 (AMS); 8 ơ ô,, Blue Mtns NP, Mt. Wilson, Waterfall Ck, 13.xii.1998 (ANIC); $1 \hat{\sigma}$, Blue Mtns NP, Popes Glen, 31.x.1994 (AMS); $2 \widehat{\jmath}^{\widehat{\delta}}$, Blue Mtns NP, Valley of the Waters below Vera Falls, 320 m, 9.iv.1995 (ANIC); $7 \hat{o} 0$, 8 $q$ o (incl. $2 \delta \hat{o}$ reared from pupae), Sydney, Edgecliff, Trumper Pk, cliff seepage,

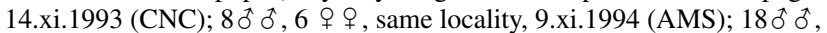
5 우, Sydney, Kirribilli, roadcut seep, 5.xi.1993 (AMS, ANIC); 10 , 1 우, Sydney, Mosman, Ashton Pk, stream, 31.x.1993 (AMS); 1 ठิ, Wentworth Falls, Jamison Ck /seeps, 10.xi.1993 (ANIC); 8 ô ô, 1 우, Wentworth Falls,
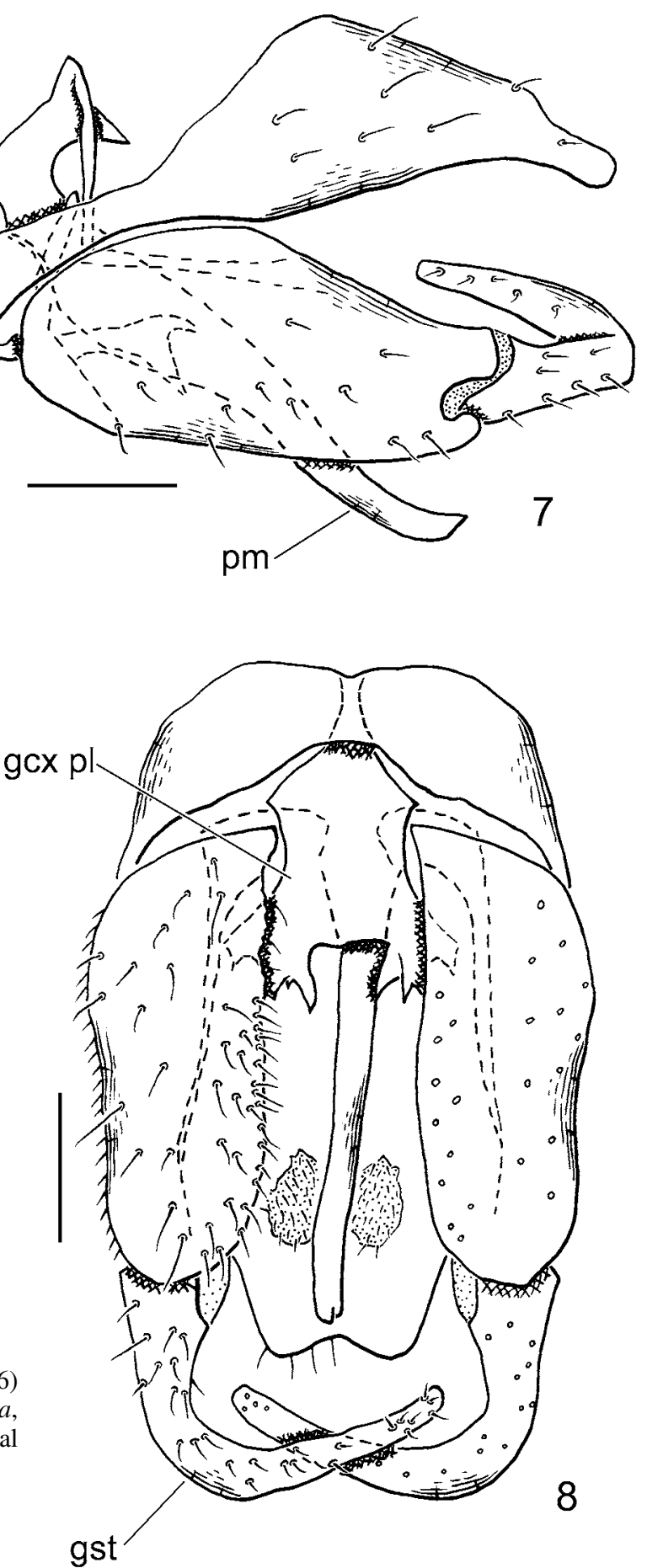

Valley of the Waters, cascading ck, 3.i., 23.x.1994, 9.iv.1995 (AMS). Queensland: 10, Bunya Mtns NP, Paradise Falls, 8.x.2002 (ZFMK). Victoria: $4 \hat{\jmath}$ ô, 1 ㅇ, Mt. Buffalo NP, Eurobin Ck, 400 m, 30.xi.1994 (CNC);

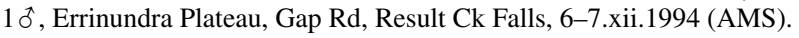

Distribution. The species ranges from Tasmania to south of Townsville, Queensland.

Remarks. The larva and pupa of this species were described by Sinclair (2000). The gonocoxal plate bears a crown of minute denticles along the ventral margin, directed anteriorly. These denticles are not shown in Theischinger (1986, fig. 31). 


\section{Austrothaumalea macalpinei Theischinger}

Austrothaumalea macalpinei Theischinger, 1986: 301.

Material examined. New South Wales: $10 \hat{\sigma}$, Barrington Tops NP,

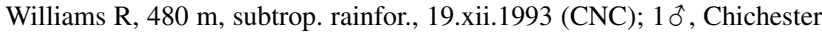
SF, trib of Williams R, 600 m, 19.xii.1993 (AMS).

Distribution. This species is confined to New South Wales.

Remarks. The gonocoxal plate bears two groups of minute denticles on either side of the mid-line along the ventral margin, directed anteriorly. These denticles are not shown in Theischinger (1986, fig. 39).

\section{Austrothaumalea minnamurrae Theischinger}

Austrothaumalea minnamurrae Theischinger, 1986: 304.

Material examined. New South Wales: $1 \hat{\delta}$, Blue Mtns NP, Blackheath, Grose Gorge, Govetts Ck, 1.xii.1993 (CNC); 2 ô ồ, Blue Mtns NP, Valley of the Waters, cascading ck, 320 m, 3.i.1994, 9.iv.1995 (AMS); 10,7 km E Robertson, Macquarie Pass NP, 23.xi.1993 (CNC). Queensland: 10 , Bunya Mts NP, face of Little Falls, 8.ix.2002 (ZFMK). Victoria: 10 , Mt. Buffalo NP, Eurobin Ck, 30.xi.1994 (AMS).

Distribution. This species ranges from southern Queensland to northern Victoria.

Remarks. The specimen from Woombye that was only tentatively included by Theischinger (1986) in A. minnamurrae is undoubtedly an undescribed species. Unfortunately, this specimen has been lost (see Acknowledgments).

The Bunya Mts specimen listed above possesses gonostyli with broad bases, similar to the Woombye species illustrated by Theischinger (1986, fig. 48). However all other key characters (e.g., shape of gonocoxal plate, lateral epandrial lobe) are very similar to that typical of A. minnamurrae.

\section{Austrothaumalea queenslandensis n.sp.}

Fig. 6

Type material. HоLоTуPE $\hat{o}$ "AUST: N.QLD: $400 \mathrm{~m} /$ Bellenden Ker N.P. /Kearneys Falls /23.iv.1994 /B.J. Sinclair"; "HOLOTYPE / Austrothaumalea /queenslandensis /Sinclair [dissected]" (AMS). PARATYPES: Queensland: $2 \%$ \% Mt. Windsor Tableland, $1000 \mathrm{~m}$, creek, $16^{\circ} 26^{\prime} \mathrm{S} 145^{\circ} 12^{\prime} \mathrm{E}, 16 . i v .1994$, B.J. Sinclair (AMS).

Recognition. This species is similar in colouration to $A$. zentae but is distinguished by its shorter paramere and pair of apical teeth-like projections on the gonocoxal plate.

Description. Wing length 1.8-1.9 mm. Coloration: Head dull, dark brown. Thorax brownish-orange, somewhat shiny; legs pale yellow, becoming darker on apical tarsal segments; halter knob dark; abdomen dull greyish-brown, including pleural membrane; terminalia pale brown. Wing infuscate, darker along apical margin, especially at cell $\mathrm{r}_{1+2}$; wing base pale, especially along wing folding; $R+R_{1}+R_{1+2}$ with macrotrichia along entire length, remaining veins bare; $R_{2}$ situated towards apex of $R_{1}$; bend in $R_{3}$ sharply defined; $R_{3}$ and $\mathrm{R}_{4+5}$ parallel toward wing margin; $\mathrm{CuA}$ with short basal appendage. Male abdominal sternites 1 and 2 not examined; 3-6 rectangular, sparsely setose; sternite 7 reduced to narrow, rectangular sclerite; sternite 8 membranous. Male terminalia (Fig. 6): Epandrium broadly trapezoidal from ventral aspect; posterior margin somewhat uneven with pair of small, round lateral knobs; lacking pointed posterolateral processes. Hypandrium broad, with deep median U-shaped cleft, nearly one-half width of base of gonostylus. Gonocoxite long, gradually tapering. Gonostylus long, curved strongly before mid-length; gradually tapering to blunt tip; apical half lacking setulae. Parameres fused to form long tube, slightly arched from lateral aspect; subequal in length to gonocoxites. Gonocoxal plate Y-shaped, secondarily fused to ventral surface of hypandrium; posterolateral corners with pair of tooth-like processes.

Distribution. This represents the most northerly described species of thaumaleid recorded in Australia, collected at an altitude of $400 \mathrm{~m}$ or above.

Etymology. Named for its restriction to the northern tablelands of Queensland.

Remarks. The small pointed, knob-like lateral projections on the gonocoxal plate are very similar to A. macalpinei (not shown in Theischinger [1986, fig. 39]).

\section{Austrothaumalea ramosa n.sp.}

\section{Figs 7-8}

Type material. HoLotype ô "AUST: NSW: Blue Mtns /N.P., Blackheath, seeps /below Govett's Leap/Lookout, 1.xii.1993/B.J. Sinclair"; "HOLOTYPE /Austrothaumalea /ramosa /Sinclair" (AMS). PARATYPES: New South Wales: $14 \hat{\widehat{\partial}} \hat{\jmath}$, same data as holotype (AMS, ANIC, CNC);

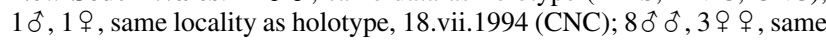
locality as holotype, 17.x.2002 (CNC, ZFMK); $3 \hat{\delta} \widehat{\delta}, 1$ 웅, Blue Mtns NP, Grand Canyon, 25.xii.1993, B.J. Sinclair (AMS); $10^{\dagger}$, Royal NP, roadcut seeps nr National Falls, 29.xii.1993, B.J. Sinclair (AMS); $2 \hat{\widehat{\partial}} \widehat{\text {, Wentworth }}$ Falls, Jamison Ck /seeps, 10.xi.1993, B.J. Sinclair (AMS); $20 \widehat{\delta}$, Wentworth Falls, Valley of the Waters, 3.i., 23.x.1994, B.J. Sinclair (AMS).

Recognition. This is a relatively large species with dark brown gonostyli, distinguished from all other described Australian species of Austrothaumalea by the pointed antlerlike processes on the posterior corners of the gonocoxal plate.

Description. Wing length 2.6-3.0 mm. Coloration: Head dull, dark brown. Mesonotum dark brown and shiny, pleura brown, especially ventrally; coxae and femora pale brown, becoming darker on apical leg segments; halter knob dark; abdomen dull greyish-brown, including pleural membrane; terminalia shiny brown, becoming darker towards apex of epandrium and gonocoxites, gonostyli dark brown. Wing evenly darkly infuscate; $\mathrm{R}+\mathrm{R}_{1}+\mathrm{R}_{1+2}$ with macrotrichia along entire length, remaining veins bare; $R_{2}$ situated towards apex of $R_{1}$; bend in $R_{3}$ gentle, not strongly defined; $R_{3}$ and $\mathrm{R}_{4+5}$ divergent toward wing margin; CuA lacking basal appendage. Male abdominal sternite 1 comprising narrow band with broad-shaped posterior notch; sternite 2 reduced to slender, median sclerite, with broad, $\mathrm{W}$-shaped, posterior apex; sternites 3-5 rectangular, sparsely setose; sternite 6 broadly triangular, anterior margin darkly pigmented; sternite 7 reduced to narrow, rectangular sclerite; sternite 8 reduced to pair of small round sclerites positioned ventral to base of gonocoxal plate. Male terminalia (Figs 7-8): Epandrium broadly triangular from ventral aspect; posterior margin with pair of small, round lobes; lacking pointed posterolateral processes. Hypandrium broad, nearly subequal to width of 
base of gonocoxites. Gonocoxite long, gradually tapering. Gonostylus long, curved strongly before mid-length; gradually tapering to blunt tip; lacking setulae. Parameres fused to form long tube, slightly arched from lateral aspect; longer than gonocoxites. Gonocoxal plate secondarily fused to ventral surface of hypandrium; posterior corners expanded into 4 pointed antler-like prolongations.

Distribution. This species was collected in Blue Mountains National Park, west of Sydney. Adults were collected in seepages and streams bordered by subtropical rainforest. In addition, a single specimen was collected in Royal National Park, south of Sydney; unfortunately the habitat was severely burned during the bush fires of 1994 .

Etymology. The specific name is from the Latin ramosus (branchy), in reference to the multi-branched or antler-like gonocoxal plate.

\section{Austrothaumalea sinuosa Theischinger}

Austrothaumalea sinuosa Theischinger, 1986: 307.

Material examined. Victoria: $2 \hat{\delta} \delta$, Errinundra Plateau, Gap Rd, Result Ck Falls, 6-7.xii.1994 (AMS); 1 ㅇ, Mt. Buffalo NP, Eurobin Ck, 400 m, 30.ix.1994 (AMS).

Distribution. This species is confined to southeastern New South Wales and northern Victoria.

Remarks. The gonocoxal plate bears a crown of minute denticles at the apex of each lateral arm. These denticles are not shown in Theischinger (1986, fig. 62).

\section{Austrothaumalea spinosa Theischinger}

Austrothaumalea spinosa Theischinger, 1986: 307.

Material examined. New South Wales: $2 \hat{\delta} \hat{\sigma}$, Blue Mtns NP, Blackheath, Govetts Leap, 17.x.2002 (ZFMK); 10 , Blue Mtns NP, Valley of the Waters, below Vera Falls, 320 m, 9.iv.1995 (AMS); 10 , Wentworth Falls, Jamison Ck/seeps, 10.xi.1993 (CNC); 2 ô कै, Kosciusko NP, Thredbo, $1300 \mathrm{~m}$, roadcut seeps, 28.xi.1994 (AMS). Victoria: $1{ }^{\dagger}$, Otway NP, Maits Rest, temp. rainfor., ck, 4.xii.1994 (ANIC); $20 \hat{0}, 2$ 우 + , Otway Ranges, Melba Gully SP, temp. rainfor., ck, 4.xii.1994 (AMS).

Distribution. This species is widespread in southeastern Australia from the Blue Mountains in New South Wales to Tasmania.

Remarks. There is some variation in the length of the apical spines on the gonocoxal plate, as well as differences in the length of the lateral epandrial process. More northern populations appear to have less pronounced spines on the gonocoxal plate.

\section{Austrothaumalea theischingeri n.sp.}

$$
\text { Figs 9-10 }
$$

Type material. HOLOTYPE $\delta$ "[AUST]: Blue Mtns. /NP, Blackheath, Govetts /Leap, seeps along track /12.xii.1998/B.J. Sinclair"; "HOLOTYPE /Austrothaumalea /theischingeri /Sinclair" (AMS).

Recognition. This species is similar to A. uloola, distinguishable by the form of the gonocoxal plate.
Description. Wing length $1.8 \mathrm{~mm}$. Coloration: Head dull, dark brown. Mesonotum and pleura brown and somewhat shiny; legs paler than thorax; halter knob concolorous with legs; abdomen dark brown. Wing evenly infuscate; $\mathrm{R}+\mathrm{R}_{1}+\mathrm{R}_{1+2}$ with macrotrichia along entire length, remaining veins bare; $R_{2}$ situated towards apex of $R_{1}$; bend in $R_{3}$ well defined; $\mathrm{R}_{3}$ and $\mathrm{R}_{4+5}$ divergent toward wing margin; $\mathrm{CuA}$ with short basal appendage. Male abdominal sternite 1 narrow, spectacle-shaped; sternite 2 reduced to slender, median sclerite, with pair of small, posterolateral sclerites; sternites 3-6 rectangular, sparsely setose; sternite 7 trapezoidal-shaped, with several marginal setae; sternite 8 narrow, one-third length of sternite 7. Male terminalia (Figs 9-10): Epandrium broadly triangular from ventral aspect; posterior margin broad, folded internally, apex with pair of small rounded lobes; sharply pointed posterolateral processes present. Hypandrium broad, one-half width of base of gonostylus. Gonocoxite broad, somewhat narrower at apex. Gonostylus shorter than gonocoxites, gradually curved, tapered; clothed in setulae; apex partially flattened. Parameres fused to form short, laterally flattened, broad blade-like process arched lengthwise. Gonocoxal plate broad basally; median portion darkly pigmented as pair of ridges leading to 2 pairs of divergent digitiform processes; basally not fused to hypandrium.

Distribution. This species is known only from the holotype, the type locality of which is a densely wet, vast seepage area where at least seven species of thaumaleids are recorded.

Etymology. The specific name honours Günther Theischinger, who made the first careful study and revision of Australian thaumaleids.

Remarks. On the basis of the posterolateral epandrial processes, apex of epandrium and shape of the paramere, this species is most closely related to A. uloola.

\section{Austrothaumalea uloola n.sp.}

Figs $11-12$

Type material. HoLOTYPE $\delta$ "AUST:NSW: Royal /N.P., Uloola Falls /17.xii.1993, seep behind /falls, B.J. Sinclair"; "HOLOTYPE / Austrothaumalea/uloola /Sinclair" (AMS). PARATYPES: New South Wales:

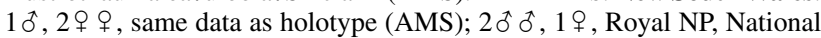
Falls, 29.xii.1993, B.J. Sinclair (ANIC); 10, Royal NP, Uloola Falls, dry sclerophyll, 23.xi.1993, B.J. Sinclair (CNC).

Recognition. This species is distinguished by the folded apical margin of the epandrium and short gonocoxal plate with small circular apex.

Description. Wing length 1.8-2.0 mm. Coloration: Head dull, dark brown. Mesonotum and pleura dark brown and somewhat shiny; legs slightly paler than thorax; halter knob dark; abdomen dark brown; terminalia light brown. Wing evenly infuscate; $R+R_{1}+R_{1+2}$ with macrotrichia along entire length, remaining veins bare; $R_{2}$ situated towards apex of $R_{1}$; bend in $\mathrm{R}_{3}$ gentle, not sharply defined; $\mathrm{R}_{3}$ and $\mathrm{R}_{4+5}$ divergent toward wing margin; $\mathrm{CuA}$ with short basal appendage. Male abdominal sternite 1 narrow, spectacle-shaped; sternite 2 reduced to slender, median sclerite, with pair of small, posterolateral sclerites; sternites 3-6 rectangular, sparsely setose; sternite 7 trapezoidal-shaped, with 3 marginal setae; 

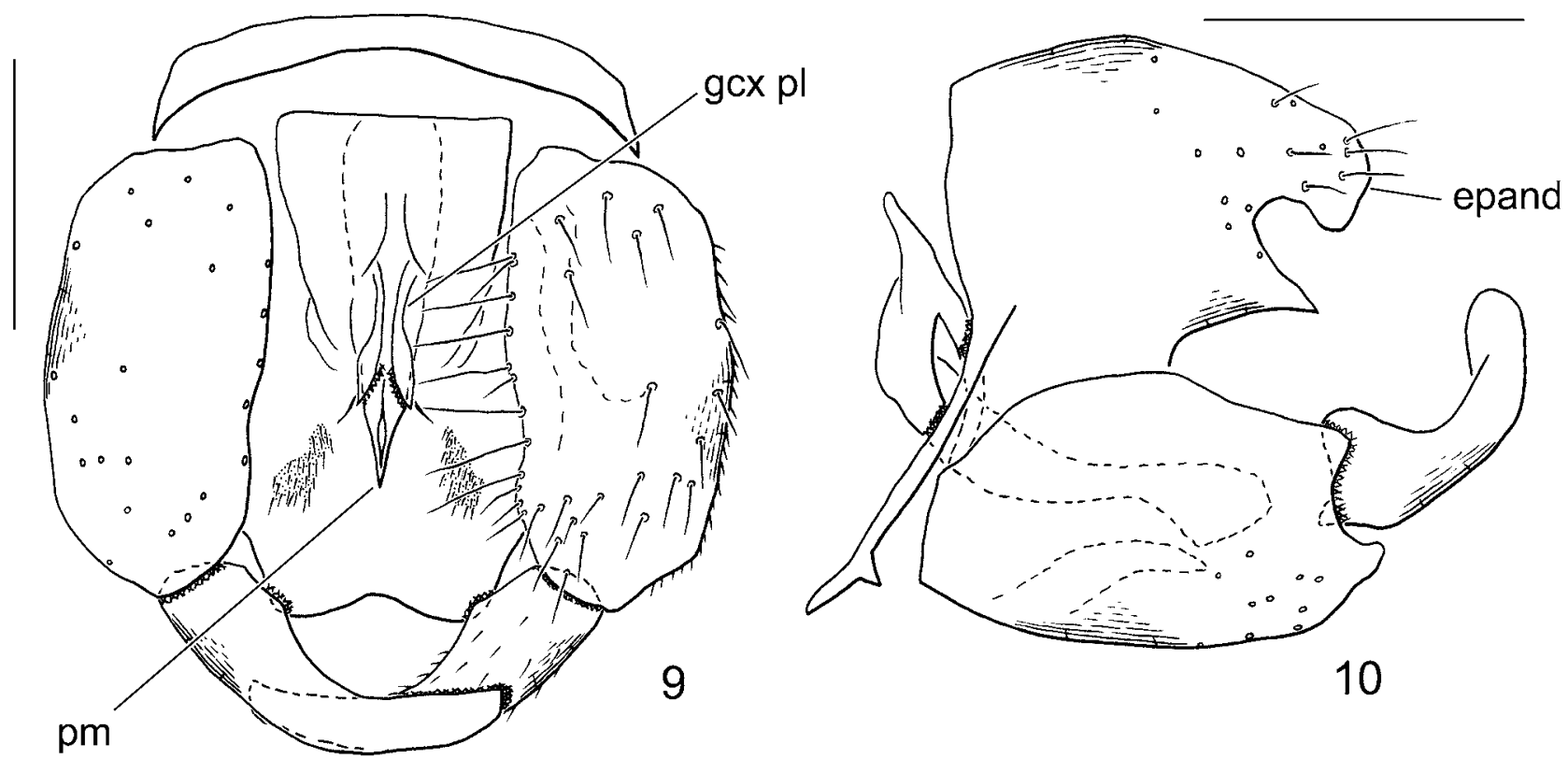

10

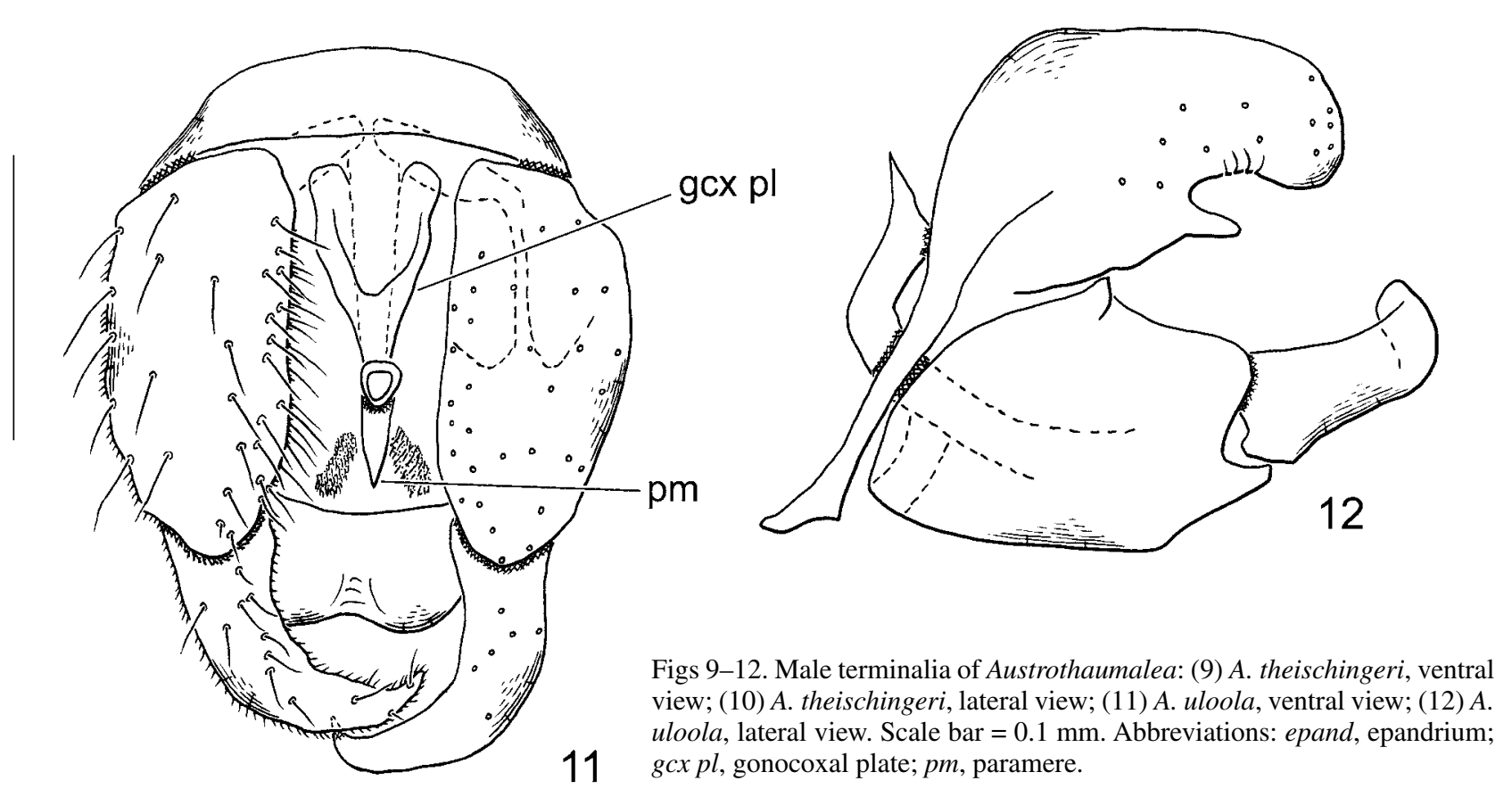

sternite 8 narrow, one-third length of sternite 7. Male terminalia (Figs 11-12): Epandrium broadly triangular from ventral aspect; posterior margin broad, folded internally, apex with pair of small rounded lobes; pointed posterolateral processes present. Hypandrium broad, one-half width of base of gonostylus. Gonocoxite broad, somewhat narrower at apex. Gonostylus shorter than gonocoxites, gradually curved, tapered; clothed in setulae. Parameres fused to form short, laterally flattened, broad blade-like process arched lengthwise. Gonocoxal plate with pale central portion; apical half strongly tapered with circle-shaped apex; basally not fused to hypandrium.

Distribution. This species is recorded from Royal National Park, just south of Sydney. Adults were swept from seepages and wet vegetation hanging beneath or behind the falls. These falls are surrounded by dry sclerophyll forest.
Etymology. Named after the type locality, Uloola Falls.

Remarks. See under A. theischingeri.

\section{Austrothaumalea victoriae Theischinger}

Austrothaumalea victoriae Theischinger, 1986: 311.

Material examined. New South Wales: $2 \hat{\delta} \hat{o}$, Kosciusko NP, Kosciusko Rd, 1600 m, upper Pipers Ck, 7.xii.1994 (CNC). Victoria:

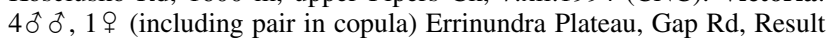
Ck Falls, 6-7.xii. 1994 (AMS); 4 ô ठิ, 9 km N Warburton, Cement Ck, 1-3.

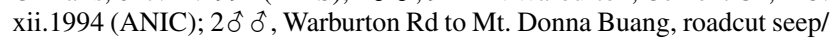
stream, 3.xii.1994 (AMS).

Remarks: The specimens from Kosciusko bear a pair of short lateral epandrial processes on each side, rather than a single pointed process. 


\section{Austrothaumalea zentae Theischinger}

Austrothaumalea zentae Theischinger, 1986: 313.

Material examined. New South Wales: $4 \hat{\delta} \hat{o}, 1 \uparrow$, Barrington Tops NP, Williams R, 480 m, subtrop. rainfor., 19.xii.1993 (ANIC); 3 ô के, Blue Mtns NP, Blackheath, Govetts Leap, cliff edge trail 25.xii.1993, 12.xii.1998 (CNC); 1 ${ }^{\star}$, Blue Mtns NP, Mt. Wilson, Waterfall Ck, 13.xii.1998 (AMS); 5 ơ o, Blue Mtns NP, Valley of the Waters, below Vera Falls, 320 m, 3.i.1994, 9.iv.1995 (CNC); $1 \hat{0}, 1$ 을 Border Ranges NP, Brindle Ck, Evans Falls, 1000 m, 25.i.1995 (AMS); 2 đో , Dorrigo NP, Rosewood Ck, 23.i.1995

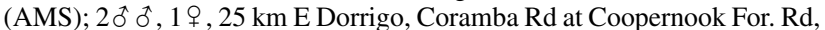
cascading ck, 2.iv.1995 (AMS); 10 , 2 ㅇ ๆ, Kosciusko NP, Guthega Rd, 1400 m, Pipers Ck, 28-29.xi.1994 (AMS); 1 oे, Kosciusko NP, Thredbo, 1300 m, roadcut seep, 28.xi.1994 (CNC); 6 ô ô, Royal NP, Uloola Falls, 27.xi., 17.xii.1993 (CNC); 1 ô, Wentworth Falls, Jamison Ck /seeps, 10.xi.1993 (ANIC). Queensland: Windsor Tablelands, $16^{\circ} 14^{\prime} \mathrm{S} 145^{\circ} 00^{\prime} \mathrm{E}, 1200 \mathrm{~m}$,

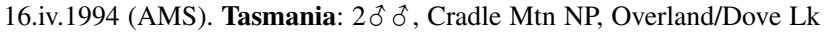
Trail, 900-1100 m, 21.ii.1994 (ANIC); 18 ô ô, 6 우 ․, Cradle Mtn NP, Pencil Pine Ck, 800 m, 20.ii.1994 (AMS); 3 ô ô, Lyell Hwy. Franklin/

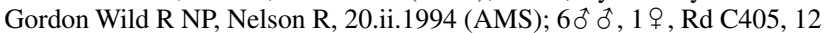
$\mathrm{km} \mathrm{N}$ of C401, 23.ii.1994 (AMS). Victoria: 10, Errinundra Plateau, Gap Rd, Result Ck Falls, 6-7.xii.1994 (AMS); 3 o ô, Mt. Buffalo NP, Eurobin Ck, 400 m, 30.xi.1994 (CNC); 3 ô ô, 9 km N Warburton, Cement Ck, 1-3. xii.1994 (AMS).

Distribution. This species is the most widespread thaumaleid in Australia, ranging from Tasmania to northern Queensland.

Remarks. The gonocoxal plate bears a patch of minute denticles near the apex of each lateral arm. These denticles are not shown in Theischinger (1986, fig. 93).

\section{Genus Niphta Theischinger \\ Niphta Theischinger, 1986: 314.}

The genus Niphta is characterized by a distinct ridge (supraalar region) in front of the wing, microtrichia of first vein $\left(\mathrm{R}+\mathrm{R}_{1}+\mathrm{R}_{1+2}\right)$ confined to base near humeral crossvein, crossvein closer to origin of $R_{3}$ than to apex of $R_{1+2}, R_{3}$ with arch not strongly produced, basal appendage of $\mathrm{CuA}$ absent, gonocoxites broad, not much longer than wide and hypandrium narrow.

\section{Niphta bickeli Theischinger}

Niphta bickeli Theischinger, 1986: 314.

Material examined. New South Wales: $4 \hat{\delta} \hat{\sigma}$, Dorrigo NP, Wonga Walk, 700 m, Crystal Shower Falls, 2.iv.1995 (AMS); 1 oे, 1 \% , Dorrigo NP, Rosewood Ck, 23.i.1995 (CNC).

Distribution. This species is confined to Dorrigo National Park.

\section{Niphta farecta Theischinger \\ Niphta farecta Theischinger, 1986: 315.}

Material examined. New South Wales: $8 \delta \hat{\delta}, 12 q \circ$, Blue Mts NP, Blackheath, Govetts Leap, seeps below lookout, 1.xii.1993, 12.xii.1998 (AMS, CNC); 4 $\widehat{\delta}$, Blue Mts NP, Valley of the Waters, cascading ck, 3.i.1994 (CNC); 3 ô ô, 2 우 9 , Blue Mts NP, Wentworth Falls, Jamison Ck, 3.i.1994 (ANIC); 1 \%, Royal NP, Flat Rock Crossing, Saw Arm Ck, 6.iii.1994 (AMS); 3 क ठิ, 2 우, Royal NP, National Falls, 29.xii.1993 (AMS); 5 oิ ô, 8 ㅇ ๆ, Royal NP, Uloola Falls, 27.xi.1993, 17.xii.1993 (ANIC).
Distribution. This species is found just west and south of Sydney, New South Wales.

\section{Additional Queensland records of Austrothaumalea}

Based on larvae (L) or undescribed females

1 Carnarvon NP, upper Carnarvon Ck, 11.x.2002 (L)

2 Blackdown Tablelands NP, Rainbow Falls, 2.v.1994 (L)

3 Eungella NP, Finch Hatton Gorge Araluen Falls, 1-200 m, Finch Hatton Ck, seepages, 30.iv.1994 (L, \&)

4 Eungella NP, roadcut seepage, below Eungella, 500 m, 30.iv.1994 (L)

5 Paluma, Mt. Spec NP, Little Crystal Ck Falls, $300 \mathrm{~m}$, seepage, 29.iv.1994 (L, + )

6 Crystal Cascades, 24 km SW Cairns, small cascading stream, iv.1994 (L)

7 Cape Tribulation $\left(16^{\circ} 10^{\prime} \mathrm{S} 145^{\circ} 27^{\prime} \mathrm{E}\right)$, Little Cooper Ck, 75 m, 14.iv.1994 (ㅇ)

\section{Discussion}

\section{Species-groups}

The following species groups are tentatively proposed for the genus Austrothaumalea. There likely remain numerous undiscovered and undescribed species which may assist in the evaluation and interpretation of these groups and their supporting characters.

Austrothaumalea appendiculata group: This species group was originally proposed by McLellan (1988) and is characterized by an arrow shaped gonocoxal plate, strongly angled gonostylus with apical setulae and lateral foliate gills on the abdomen of the pupa. The A. appendiculata group is most closely related to the A. neozealandica group on the basis of pupal foliate setae, paired apical projections on the parameres and a pair of lateral processes on the posterior margin of the epandrium. The A. appendiculata group includes: A. appendiculata Tonnoir, A. gibbsi McLellan and A. maxwelli McLellan.

Austrothaumalea barrydayi group: This group is defined on the basis of an umbrella shaped gonocoxal plate and includes the following species: A. barrydayi, A. bickeli, A. denticulata, A. similis and A. victoriae.

Austrothaumalea capricornis group: The group is characterized by a shallowly to deeply forked gonocoxal plate with its outer margins more heavily sclerotized than medially. This group includes: A. capricornis, A. chilensis Edwards (from Chile), Austrothaumalea n.sp. (from New Caledonia, see Sinclair, in press), A. commoni, A. concava, A. queenslandensis, A. ramosa, A. sinuosa, A. spinosa, A. zentae; possibly A. australis, A. macalpinei, A. simplex, A. tasmanica, A. tonnoiri and perhaps Oterere setipennis (Edwards) (see under "Phylogenetic Affinities").

Austrothaumalea fusca group: This group is defined by the distinctive truncate gonocoxal plate (although this maybe the plesiomorphic condition), with its broad base. A subgroup is characterized by forked gonostyli. The A. fusca 
group includes: A. bifida, A. cervulus, A. fusca, A. uptoni and possibly $A$. apicalis Edwards and A. spatula Schmid (both from Chile).

Austrothaumalea minnamurrae group: This group possesses slender epandrial processes and has T-shaped or arrow-head shaped gonocoxal plates. The shape of these structures are similar to the A. appendiculata group and consequently the $A$. minnamurrae group may possibly be the sister group to the New Zealand species of Austrothaumalea. The A. minnamurrae group includes A. bicornis, A. minnamurrae and Austrothaumalea sp. (Woombye).

Austrothaumalea neozealandica group: This species group was originally proposed by McLellan (1988) and is characterized by goblet-shaped or rounded lobes of the gonocoxal plate, and dorsal and lateral rows of foliate gills on the thorax and abdomen of the pupa. This group includes: A. crosbyi McLellan, A. macfarlanei McLellan, A. ngaire McLellan, A. neozealandica Tonnoir, A. pala McLellan, A. walkerae McLellan, and $A$. zwicki McLellan.

The following species are currently unplaced to species group: A. theischingeri, A. uloola.

\section{Phylogenetic affinities}

Oterere is possibly paraphyletic in relation to Austrothaumalea and is characterized by the well-developed appendage on $\mathrm{CuA}$, macrotrichia on $\mathrm{R}_{4+5}$ and patterned wings. Unfortunately these features are not unique and the male terminalia of the two assigned species $(O$. oliveri McLellan, O. setipennis) do not share derived features. In addition, $A$. tasmanica also has $\mathrm{R}_{4+5}$ bearing macrotrichia, several species have darkened wing tips, and the length of the appendage arising from $\mathrm{CuA}$ is variable in Austrothaumalea (long in A. appendiculata group).

Although relationships have been discussed and proposed by Sinclair \& Stuckenberg (1995) and Sinclair (2000), based on adult and immature characters, the phylogenetic relationships of the four Gondwanan genera of Thaumaleidae have not been formerly analyzed. Recent phylogenetic analyses attempted by this author have resulted in little support for major groupings. Greater knowledge of the South American fauna and immature stages in general would greatly assist these studies. In addition, the inclusion of molecular data sets would be a welcome addition to the search for a stable phylogeny of the Gondwanan genera and for the family Thaumaleidae.

\section{Faunal patterns}

There are now 26 known species of Austrothaumalea in Australia. One species is confined to southwestern Australia (A. australis), seven species are known from Tasmania (four endemic), five species from Victoria, 18 species from New South Wales and seven species (three endemic to Northern Queensland) known from Queensland. Austrothaumalea denticulata and $A$. zentae are the most widespread species and the latter is the most northerly recorded thaumaleid in Australia. The great number of species known from New South Wales is both a reflection of the collecting effort and the diversity of aquatic habitats, where eight species are recorded from the Blue Mountains and seven species from Royal NP (of which four are not currently recorded from the Blue Mts.).
Nearly all species were collected in various rainforest types, ranging from cool wet temperate forests, gallery forests, and lowland and upland tropical rainforests. In the Sydney region, several species were collected from seepages in surrounding sclerophyll forests (e.g., A. cervulus, A. denticulata, A. uloola), however they occur also in other various types of rainforest localities.

ACKNOWLEDGMENTS. Günther Theischinger greatly encouraged the completion of this study. The Australian Museum provided space and facilities during early stages of this study, with special thanks to the Entomology section, especially Dan Bickel. Ian McLellan (Westport, NZ) kindly provided specimens of A. appendiculata. Scott Brooks (CNC) and two anonymous reviewers provided valuable comments on earlier drafts.

The following specimens from ANIC were unfortunately lost in July 2000 by the Postal Service on route from Australia to Fukuoka, Japan (former address of author) and consequently could not be examined directly: A. nr minnamurrae (from Woombye), A. fusca (holotype), A. tonnoiri (male paratype). The location or fate of the package could not be traced.

Collecting permits were obtained through the Australian Museum and Queensland Parks and Wildlife Service (Permit No. F1/000076/02/SAA).

\section{References}

Colless, D.H., \& D.K. McAlpine, 1991. Diptera (Flies) [Chapter] 39. In The Insects of Australia, vol. 2. 2nd edition, ed. I.D. Naumann, pp. 717-786. Carlton: Melbourne University Press.

McAlpine, J.F., 1981. Morphology and terminology-adults. [Chapter] 2. In Manual of Nearctic Diptera, vol. 1., ed. J.F. McAlpine et al., pp. 9-63. Agriculture Canada Monograph 27: vi + 1-674.

McLellan, I.D., 1988. A revision of New Zealand Thaumaleidae (Diptera: Nematocera) with descriptions of new species and a new genus. New Zealand Journal of Zoology 15: 563-575.

Saigusa, T., 2006. Homology of wing venation of Diptera. A handout distributed at the 6th International Congress of Dipterology, Fukuoka, Japan. 26 pp.

Sinclair, B.J., 1992. A new species of Trichothaumalea (Diptera: Thaumaleidae) from eastern North America and discussion of male genitalic homologies. The Canadian Entomologist 124: 491-499.

Sinclair, B.J., 2000. Immature stages of Australian Austrothaumalea Tonnoir and Niphta Theischinger (Diptera: Thaumaleidae). Australian Journal of Entomology 39(3): 171-176. http://dx.doi.org/10.1046/j.1440-6055.2000.00162.x

Sinclair, B.J., in press. A new species of Austrothaumalea Tonnoir from New Caledonia (Diptera: Thaumaleidae). In Zoologia Neocaledonica 6. Biodiversity studies in New Caledonia, ed. P. Grandcolas. Mémoires du Muséum d'histoire naturelle 196.

Sinclair, B.J., \& B.R. Stuckenberg, 1995. Review of the Thaumaleidae (Diptera) of South Africa. Annals of the Natal Museum 36: 209-214.

Theischinger, G., 1986. Australian Thaumaleidae. Records of the Australian Museum 38(6): 291-317. http://dx.doi.org/10.3853/j.0067-1975.38.1986.184

Theischinger, G., 1988. Austrothaumalea bickeli spec. nov., a new thaumaleid from Australia (Insecta: Diptera: Thaumaleidae). Stapfia 17: 211-213.

Manuscript submitted 16 March 2007, and accepted 30 June 2007.

Associate Editor: D.J. Bickel. 